Journal of Applied Pharmaceutical Science Vol. 6 (12), pp. 224-232, December, 2016

Available online at http://www.japsonline.com

DOI: $10.7324 /$ JAPS.2016.601233

ISSN 2231-3354 (cC) BY-NC-SA

\title{
Clinical trials studies of plant extracts with anti-inflammatory activity
}

\author{
Eloísa Portugal Barros Silva Soares de Souza ${ }^{1}$, Robson Xavier Faria ${ }^{2 *}$, Leandro Machado Rocha ${ }^{1}$ \\ ${ }^{1}$ Laboratório de Tecnologia de Produtos Naturais, Universidade Federal Fluminense, Mario Viana Street, 523. Santa Rosa, Niterói, Brazil. \\ ${ }^{2}$ Laboratório de Toxoplasmose e outras Protozooses, Fiocruz, Brasil Avenue, 4365, hall 108, room 34, Rio de Janeiro, Brazil.
}

\begin{tabular}{l} 
ARTICLE INFO \\
\hline Article history: \\
Received on: $26 / 04 / 2016$ \\
Revised on: 04/07/2016 \\
Accepted on: $11 / 09 / 2016$ \\
Available online: $28 / 12 / 2016$ \\
\hline Key words: \\
Plant extracts, anti- \\
inflammatory, clinical trials.
\end{tabular}

\begin{abstract}
The therapeutic potential of medicinal plants has been studied and evaluated in scientific circles. The antiinflammatory activity was established as being of great importance, by considering the number of diseases that it involves, the high investment of industries and adverse effects of patients. There is no doubt that this is a promising way in many cases, due to the diversity of structures and substances contained in plants. But although many of the plant extracts have been evaluated against activities in vitro and in vivo, not all reached the stage of clinical trials in humans in order to reach someday the pharmaceutical market. Some phytochemical studies also seek a biologically active isolated molecule. Our purpose with this study is to show the plants whose antiinflammatory activity has already been studied in pre-clinical trials and that where conducted clinical studies in humans, providing a new observation perspective of herbal products, regardless of a search for a synthesizable isolated substance, with the knowledge of the activity of one or more extracts as a whole.
\end{abstract}

\section{INTRODUCTION}

Inflammation is known as a response to a harmful stimulus, whose intensity is related to the size of the stimulus, causing symptoms such as heat, redness, pain and swelling. The inflammatory response can be divided into three phases: acute inflammation, chronic inflammation and immune response (Luengo, 2005; Smyth et al., 2011). Acute inflammation is mediated by the autacoids release in response to injury or trauma. It consists in an essential mechanism for survival. But it can cause serious adverse effects if sustained by excessive and prolonged manner by the body, resulting in chronic inflammation in which there is a feedback mechanism with the generation of many harmful mediators to the organism (Luengo, 2005; Smyth et al., 2011). At the cellular level, in this process, the release of arachidonic acid occurs from membrane phospholipids and, consequently, its metabolites: prostaglandins, prostacyclins, thromboxane A2, leukotrienes, lipoxinsand hepoxilins, known as eicoisanoids (Smyth et al., 2011).

\section{* Corresponding Author}

Robson Xavier Faria, Laboratório de Toxoplasmose e outras

Protozooses, Fiocruz, Brasil Avenue, 4365, hall 108, room 34, Rio de

Janeiro, Brazil.Email: robson.xavier@gmail.com
The eicosanoids are synthesized by two classes of enzymes: the cyclooxygenases (prostaglandin, prostacyclin and thromboxane), known as prostanoids, and the lipoxygenases (leukotrienes and lipoxins). The main mechanism of action of antiinflammatory non-steroidal drugs consists in inhibiting the cyclooxygenase, the first enzyme of prostaglandin synthetic pathway (Smyth et al., 2011). Due to the presence of these two isoforms of the enzyme, one of the most common adverse effects of NSAIDs are gastric disorders associated with simultaneous inhibition of COX-1 and COX-2, since the constitutive COX-1 enzyme has an important role in protecting the stomach lining (Kummer and Coelho, 2002). Those that selectively inhibit COX2 , known as coxibs, were withdrawn from the market in some countries due to cardiac disorders, hepatotoxicity and sudden cardiac death (Bombardier et al., 2000).

Other drugs used in the inflammation are the modifying disease anti rheumatics, including some anti cytokines and immunosuppressive drugs, and other biopharmaceuticals. These latter, came from recombinant engineering techniques, are limited by its high cost because of the difficulty in production (Rang et al., 2012). Antimalarial drugs also have anti-inflammatory action primarily in connective tissue disorders and they are used in the autoimmune diseases maintenance (Fox et al., 2007). 
The glucorticosteroids are considered the most potent drugs against inflammation, but they are also known for their toxic effects on the body, if used in high doses and for prolonged periods of time, or for therapy discontinuation (Scimmer et al., 2007). In this context, an increasing interest in activities medicinal plants has been observed. It is remarkable the importance that medicinal plants always had and have been growing in recent years. Man's relationship to nature in seeking his basic needs such as food, clothing and transportation, and, among others of no less importance, the cure of diseases, is a millennial practice that accompanies him from ancient times to the present day. In the simple act of making a tea with a plant to improve the symptoms of a cold, there was a "technology" behind it, which had been exploited over the years to prepare plant extracts (Gurib-Fakim, 2006).

The scientific community has been exploring more and more this therapeutic potential and endless source of biologically active molecules in the search for new drugs. It is worth mentioning that large contributions of medicine came from plants, such as, for example, morphine, digoxin, pilocarpine and acetylsalicylic acid, and more recently an important discovery in the anticancer area was paclitaxel. Such findings point to what is already known about the importance of medicinal plants and generate hope and encouragement to the search for plant-derived new drugs (Filho and Yunes, 1998).

From the plant extracts are taken the components it has, with activity or not, and from the extract fractions with different solvents and polarities rich mixtures in their components are selected, such as tannins, alkaloids, terpenoids, flavonoids. These latter, especially, have anti-inflammatory activity demonstrated in vitro and in vivo. This activity is of great importance due to the amount of diseases primarily generated by increased inflammatory response of the body (Kim et al., 2004). The aim is to know which of these pre-clinical trials have reached the stage of clinical trials in humans. In the West, the use of natural products and their importance have grown considerably in recent years, while in the East this practice has always been a common practice. Due to a very strong pharmaceutical industry and a very rigid legislation, it becomes more difficult the adoption of alternative medicine studies, which still lack a quality control and scientific evidence of its effectiveness (Yuan and Lin, 2000). This article seeks to do a review about plant extracts with anti-inflammatory activity tested in humans. It also seeks to know how the results were obtained and what are the future perspectives, in order to give an overview of the plants, their components and the activities in the antiinflammatory field. So, opening a new perspective of natural products observation regardless of a search for a synthesizable isolated substance, but the understanding of the activity of one or more extracts as a whole.

\section{MATERIALS AND METHODS}

A literature search was held on the internet databases SciFinder, Web of science and Pubmed using as keywords plant extracts, clinical trial and inflammatory. Inflammatory diseases mentioned in the articles are separated into categories according to the involvement location in the body, and each is selected one or more clinical trials in the area.

The inclusion and exclusion criteria used were as follows: articles which tests were conducted on animals or in vitro assays were excluded, considering only clinical studies in humans. Were included in this work studies with one or more plants, disregarding synthetic compounds or isolated substances from plants. They were considered clinical trials in patients with typical inflammatory diseases. Inflammations resulting from parasitic infections or inflammatory processes not classified as diseases were excluded. The study selection process is presented in Figure 1.

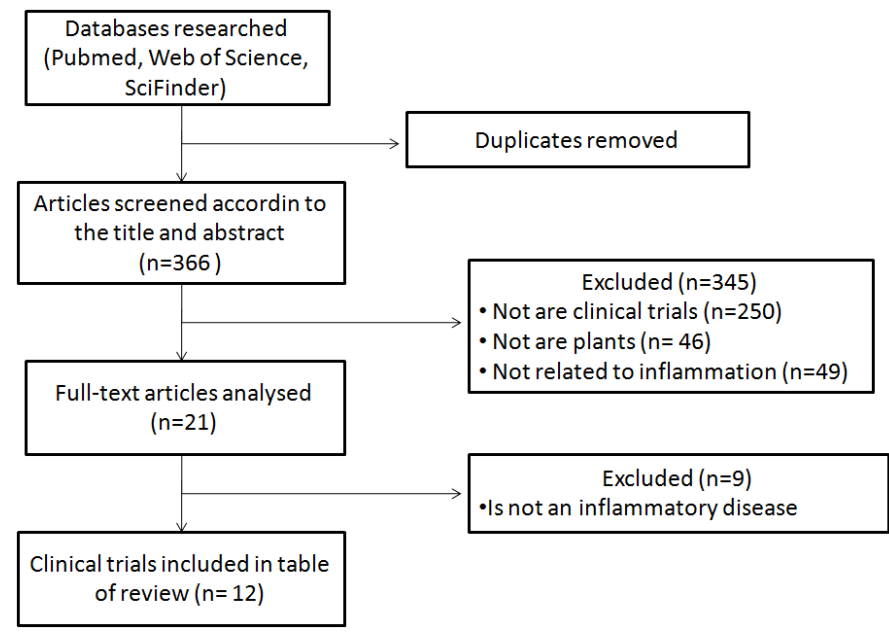

Fig. 1: Diagram of selection of articles for review accordin to inclusion and exclusion criteria used.

\section{RESULTS}

Inflammatory diseases can be different when one takes account those that are triggered by inflammatory processes and those with worsening condition due to the inflammation. They can affect the whole body from the skin and the Respiratory tract to the internal organs and the immune system itself.

An example of inflammatory disease is bronchial asthma. This is a respiratory chronic inflammation that results from genetic and environmental factors. In that disease, there is an increased transcription of inflammatory genes regulated by proinflammatory transcription factors such as nuclear factor-kB (NF-kB) and activator protein 1 (AP-1). These encode inflammatory cytokines and other molecules that induce and sustain inflammation. The mechanism of action of corticosteroids, very potent drugs in the asthma treatment, consists in the histone acetylation reversion and subsequent suppression of gene transcription (Campos, 2007).

Rheumatoid arthritis is an autoimmune disease in which there is an inflammation of the synovial membrane and consequent progressive degradation of the cartilages that coat the bones and joints. The major pro-inflammatory mediators are vascular adhesion molecules and metalloproteinases, in addition to various 
cytokines (IL-1 $\beta$, IL-6, IL-15, TNF- $\gamma$, TNF- $\alpha$ ) (Liu et al., 1996). In these cases, drug therapy depends on the stage and severity of the disease. Usually NSAIDs, biological agents or disease modifying drugs, are used. Small doses of glucocorticosteroids may be used in conjunction with some of these therapies (Laurindo et al., 2004).

Still talking about autoimmune inflammatory diseases, Systemic lupus erythematosus affects multiple organs and systems. Due to a flaw in the immune system, the antibodies production directed against proteins in the body may occur. This condition leads to cell destruction by phagocytic cells and to cytotoxicity by immunocompetent cells. Depending on the severity of the disease and the possibility of death, high doses of glucocorticosteroids can be used in active disease phase. Antimalarial drugs and immunosuppressive drugs can also be used in remission phase in order to keep the disease under control and save the body from the effect of corticosteroids (Balbi et al., 2001; Sato et al., 2008). Inflammatory processes, as well as the mechanisms of action of the different drugs used for this purpose, can vary widely, including inflammatory markers observed in diseases differ from each other. And, depending on the place of action, the intensity of the inflammation, the stage of disease and the treatment time, among other factors, differ from the drugs used in therapy. In addition, the factors that lead patients to inflammation also vary and may originate from genetic predisposition, environmental factors and infectious agents, among the most diverse. The various inflammatory diseases, separated by their site of action in the body and their respective species of plants used are shown in Table 1.

Table 1: Anti-inflammatory plants in clinical trials phase described in this work separate by category.

\begin{tabular}{|c|c|c|c|c|c|c|}
\hline & $\begin{array}{l}\text { Inflammatory } \\
\text { disease }\end{array}$ & Specie(s) of Plant(s) & $\begin{array}{c}\text { Control } \\
\text { (reference drug } \\
\text { or placebo) }\end{array}$ & $\begin{array}{l}\text { Type of study, } \\
\text { sample, sex } \\
\text { (F:M), age }\end{array}$ & $\begin{array}{c}\text { Outcomes measured and } \\
\text { results }\end{array}$ & Reference \\
\hline \multirow[t]{3}{*}{ 苛 } & Bronchiolitis & $\begin{array}{l}\text { Loniceya japonica, } \\
\text { Scutellaria baicalensis, } \\
\text { Forsythia suspensa }\end{array}$ & $\begin{array}{l}\text { Lincomycin } 30 \\
\mathrm{mg} / \mathrm{kg} / \mathrm{day}, \\
\text { cephazolin } 100 \\
\mathrm{mg} / \mathrm{kg} / \text { Day }\end{array}$ & $\begin{array}{l}\text { Single-blind, } 96 \text {, } \\
\text { F/M: 32/64, 2-48 } \\
\text { months }\end{array}$ & $\begin{array}{l}\text { Reduction in days of symptoms } \\
\text { for antibiotics versus TCM: } \\
\text { fever: } 2.7(1.9-3.8) \text { for } 1-5(1.2- \\
\text { 2.0); Cough: } 7.7(6.7-8.9) \text { for } 6.1 \\
(5.3-6.9) \text {; wheezing: } 6.1(5.2- \\
7.3) \text { for } 4.2(3.7-4.9) \text {; chest } \\
\text { congestion: } 7.7(6.7-8.9) \text { for } 4.9 \\
(4.0-5.9) \text { p p } 0.01\end{array}$ & $\begin{array}{l}\text { (Kong et al., } \\
\text { 1993) }\end{array}$ \\
\hline & Asthma & $\begin{array}{l}\text { Bupleurum falaztum } \\
\text { Linne, Pinellia ternata } \\
\text { Breitenbach, Pork cocos } \\
\text { Wolf, Scutelkzriu } \\
\text { baiealensis Georgi, } \\
\text { Zizyphus vulgaris Lamark, } \\
\text { Panax ginseng C. A. } \\
\text { Meyer, Magnolia } \\
\text { officinalis, Glycyrrhiza } \\
\text { glabra L., Perillae } \\
\text { frutescens Britton, } \\
\text { Zingiber officinale Roscoe. }\end{array}$ & Placebo & $\begin{array}{l}\text { Double-bling } \\
\text { randomized, } 33 \\
\text { F/M: } 18 / 15,42 \pm 7 \\
\text { (SD) years }\end{array}$ & $\begin{array}{l}\text { Reduction in } \% \text { of eosinophils } \\
\text { before and after treatment: with } \\
\text { Tj-96 versus placebo: } 9,8 \pm 4,8 \text { to } \\
5,3 \pm 2,5 \text { versus } 9.5 \pm 5.3 \text { to } \\
9.3 \pm 4.9 \text { (blood) and } 13.9 \pm 7.7 \text { to } \\
5.3 \pm 4.5 \text { versus } 12.9 \pm 6.6 \\
13.8 \pm 8.2 \text { (Sputum). And ECP } \\
\text { (mg/L sputum) } 729 \pm 326 \text { to } \\
180 \pm 46 \text { versus } 736 \pm 315 \text { to } \\
747 \pm 318 . \text { p }<0.05\end{array}$ & $\begin{array}{l}\text { (Urata et al., } \\
\text { 2002) }\end{array}$ \\
\hline & Allergic rhinitis & $\begin{array}{l}\text { Rehmannia glutinosa, } \\
\text { Scutellaria baicalensis, } \\
\text { Polygonatum sibiricum, } \\
\text { Ginkgo biloba, Epimedium } \\
\text { sagittatum, Psoralea } \\
\text { corylifolia, Schisandra } \\
\text { chinensis, Prunus mume, } \\
\text { Ledebouriella divaricata, } \\
\text { Angelica dahurica } \\
\text { Astragalus membranaceus }\end{array}$ & Placebo & $\begin{array}{l}\text { Double-blind } \\
\text { randomized, 58, } \\
\text { F/M: } 21 / 37,18-65 \\
\text { years }\end{array}$ & $\begin{array}{l}\text { Reduction on Serum IgE }(\mathrm{ku} / \mathrm{L}) \\
\text { median (LQ, UQ) before and } \\
\text { after treatment with placebo } \\
\text { versus Biminne: } 189(96,529) \text { to } \\
194(98,459) \text { versus } 288(116 \text {, } \\
641) \text { to } 238(104,564)\end{array}$ & (Hu et al., 2002) \\
\hline$\frac{\Xi}{\sqrt{*}}$ & Atopic dermatitis & $\begin{array}{l}\text { Ledebouriella seseloides, } \\
\text { Potentilla chinensis, } \\
\text { Anebia clematidis, } \\
\text { Rehmannia glutinosa, } \\
\text { Paeonia lactiflora, } \\
\text { Lophatherum gracile, } \\
\text { Dictamnus dasycarpus, } \\
\text { Tribulus terrestris, } \\
\text { Glycyrrhiza uralensis, } \\
\text { Schizonepeta tenuifolia } \\
\end{array}$ & Placebo & $\begin{array}{l}\text { Double-blind, } 40 \text {, } \\
\text { F/M: 23/17, 19-57 } \\
\text { years. }\end{array}$ & $\begin{array}{l}\text { Geometric mean score after } \\
\text { treatment with Zemaphyte } \\
\text { versus placebo: } 12.6(5.9-22) \\
\text { versus } 113(65-180) \text { for } \\
\text { erythema; and } 11.3(5.8-21.8) \\
\text { versus } 111.0(68-182) \text { for } \\
\text { surface damage. }(95 \% \mathrm{CI})\end{array}$ & $\begin{array}{l}\text { (Sheehan et al., } \\
\text { 1992) }\end{array}$ \\
\hline 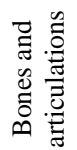 & Osteoarthritis & Zingiber officinale & $\begin{array}{l}\text { Placebo and } \\
\text { Ibuprofen } \\
400 \mathrm{mg}\end{array}$ & $\begin{array}{l}\text { Double-blind, } \\
\text { randomized, 120, } \\
\text { F/M: 31/89, 52-64 } \\
\text { years. }\end{array}$ & $\begin{array}{l}\text { VAS }(\mathrm{mm}) \text { of gelling pain after } \\
\text { treatment with ginger extract: } \\
30 \pm 3.7 \text {; ibuprofen: } 28 \pm 3 \text {; } \\
\text { placebo: } 56.5 \pm 3.6 . \quad \mathrm{p}<0.05\end{array}$ & $\begin{array}{l}\text { (Haghighi et al., } \\
\text { 2005) }\end{array}$ \\
\hline
\end{tabular}




\begin{tabular}{|c|c|c|c|c|c|c|}
\hline & & $\begin{array}{l}\text { Clematis mandshurica, } \\
\text { Trichosanthes kirilowii } \\
\text { and Prunella vulgaris }\end{array}$ & Placebo & $\begin{array}{l}\text { Double-blind, } \\
\text { randomized, } 96 \text {, } \\
\text { F/M: } 87 / 9,35-75 \\
\text { years }\end{array}$ & $\begin{array}{l}\text { VAS }(\mathrm{mm}) \text { change after } \\
\text { treatment with placebo: }-7.5 \pm \\
\text { 15.5 versus SKI } 306 X 200 \mathrm{mg} \text { : } \\
-23.6 \pm 16.3 ; 400 \mathrm{mg}:-22 \pm 14 \text { and } \\
600 \mathrm{mg}: \\
-29.8 \pm 17.4 . \mathrm{p}<0,001\end{array}$ & $\begin{array}{l}\text { (Jung et al., } \\
2001 \text { ) }\end{array}$ \\
\hline & $\begin{array}{l}\text { Rheumatoid } \\
\text { arthritis }\end{array}$ & $\begin{array}{l}\text { Tripterygium wilfodii } \\
\text { Gancho } F .\end{array}$ & Placebo & $\begin{array}{l}\text { Double-blind } \\
\text { prospective, } \\
\text { controlled, } \\
\text { double-blind, } \\
\text { cross-over, } 70 .\end{array}$ & $\begin{array}{l}\text { Tenderness score, swelling } \\
\text { count, morning stiffness and grip } \\
\text { strength, } 15 \mathrm{~m} \text { walking time. } \\
\text { Patients treated with T. wilfodii } \\
\text { get improvement in all the } \\
\text { observed parameters compared } \\
\text { to placebo. }\end{array}$ & $\begin{array}{l}\text { (Soeken et al., } \\
\text { 2003) }\end{array}$ \\
\hline \multirow[t]{2}{*}{ 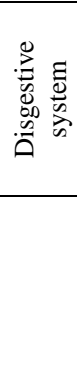 } & Gingivitis & $\begin{array}{l}\text { Punica granatum Linn. } \\
\text { and Matricaria recutita } \\
\text { Linn. }\end{array}$ & $\begin{array}{l}\text { chlorhexidine } \\
0.12 \%\end{array}$ & $\begin{array}{l}\text { Double-blind, } \\
\text { randomized, } 55 \text {, } \\
\text { F/M: } 46 / 9\end{array}$ & $\begin{array}{l}\text { Gingival bleeding index after } \\
\text { treatment with chlorhexidine } \\
(20.25 \pm 19.86, \text { chamomile } \\
31.55 \pm 21.87 \text { and pomegranate } \\
(23.60 \pm 17.07) \\
\mathrm{p}<0,001\end{array}$ & $\begin{array}{l}\text { (Batista et al., } \\
\text { 2014) }\end{array}$ \\
\hline & Crohn Disease & Artemisia absinthium & placebo & $\begin{array}{l}\text { Randomized, 20, } \\
\text { F/M: 11/9, 18-80 } \\
\text { years }\end{array}$ & $\begin{array}{l}\text { Crohn's Disease Activity Index } \\
\text { for placebo: } 282 \pm 11 \text { to } 260 \pm 14 \\
\text { and wormwood group: } 275 \pm 15 \\
175 \pm 12 .(\chi 2 \text {-test; } p=0,05)\end{array}$ & $\begin{array}{l}\text { (Krebs et al., } \\
\text { 2010) }\end{array}$ \\
\hline \multirow[t]{2}{*}{$\underset{\Xi}{\stackrel{\Xi}{\Xi}}$} & $\begin{array}{l}\text { Systemic lupus } \\
\text { erythematosus }\end{array}$ & $\begin{array}{l}\text { Rehmannia glutinosa, } \\
\text { Cornus officinalis, } \\
\text { Dioscorea opposita, } \\
\text { Alisma orientalis, Paeonia } \\
\text { suffruticosa, Salvia } \\
\text { miltiorrhiza, Panax } \\
\text { notoginseng, Blumea } \\
\text { balsamifera }\end{array}$ & $\begin{array}{l}\text { Control with } \\
10 \% \text { herbal } \\
\text { formulation and } \\
90 \% \text { starch }\end{array}$ & $\begin{array}{l}\text { Double-blind, } \\
\text { randomized, 53, } \\
\text { 18-60 years }\end{array}$ & $\begin{array}{l}\text { Systemic lupus erythematosus } \\
\text { disease activity index for control } \\
\text { group } 3.65 \pm 2.22 \text { to } 3.34 \pm 2.97 \\
\text { versus Dan-Chi-Liu-Wei } 4.30 \pm \\
2.28 \text { to } 3.47 \pm 1.08 \text {. }(\mathrm{p}<0,05)\end{array}$ & $\begin{array}{l}\text { (Liao et al., } \\
\text { 2011) }\end{array}$ \\
\hline & $\begin{array}{l}\text { Ankylosing } \\
\text { spondylitis }\end{array}$ & $\begin{array}{l}\text { Radix Astragali } \\
\text { Mongolici, Semen Coicis, } \\
\text { Radix et Rhizoma } \\
\text { Tripterygii, Scolopendra }\end{array}$ & $\begin{array}{l}\text { Salazopyrin } 1 \mathrm{~g} \\
\text { twice per day }\end{array}$ & $\begin{array}{l}\text { Randomized, } 120, \\
\text { F/M: } 20 / 100,18- \\
60 \text { years }\end{array}$ & $\begin{array}{l}\text { Xinfeng versus Salazopyrin: NF- } \\
\kappa B \text { p65 (ng/mL): } 3.82 \pm 1.95 \text { to } \\
2.42 \pm 1.06 \text { versus } 3.72 \pm 2.14 \text { to } \\
2.63 \pm 1.32 \text {. iNOS }(\mathrm{U} / \mathrm{mL}) \text { : } \\
22.72 \pm 12.53 \text { to } 15.42 \pm 9.45 \\
\text { versus } 22.91 \pm 12.24 \text { to } \\
19.73 \pm 10.42 \text {. NO }(\mu \mathrm{mol} / 1) \text { : } \\
274.14 \pm 179.12 \text { to } 188.24 \pm 91.53 \\
\text { versus } 276.42 \pm 177.91 \text { to } \\
217.43 \pm 102.52 \text {. }(\mathrm{P}<0.05 \text { or } \\
\mathrm{P}<0.01)\end{array}$ & $\begin{array}{l}\text { (Liu et al., 2013; } \\
\text { Liu et al., 2014) }\end{array}$ \\
\hline Z & Depression & Crocus sativus & Placebo & $\begin{array}{l}\text { double-blind, } \\
\text { randomized, } 230 \text {, } \\
\text { F/M: } 118 / 112,18- \\
55 \text { years }\end{array}$ & $\begin{array}{l}\text { Hamilton Rating Scale } \\
\text { for Depression. Changes at } \\
\text { endpoint compared with } \\
\text { baseline to saffron: }-12.2 \pm 4.67 \text {, } \\
\text { and }-14.01 \pm 5.53 \text {; versus } \\
\text { placebo: }-5.10 \pm 4.71 \text { and } 5.05 \pm \\
\text { 4.63. }(95 \% \mathrm{CI})\end{array}$ & $\begin{array}{l}\text { (Lopresti and } \\
\text { Drummond, } \\
\text { 2014) }\end{array}$ \\
\hline
\end{tabular}

\section{Respiratory inflammation}

A single-blind study in 96 children with bronchiolitis in China was conducted with a formulation derived from three Chinese plants: Shuanghua, huangqin and lianqiao. Shuanghua is the flower in bud of Loniceya japonica; huangqin, the root of Scutellaria baicalensis; and lianqiao, the fruit of Forsythia suspensa. Shuanghua and lianqiao possess anti-inflammatory activity assessed in preclinical trials, and the formulation has also antibacterial and antiviral activity (Yuan and Lin, 2000). This was tested with and without antibiotic, and a third group was treated with antibiotic only. It was observed a reduction in the disease symptoms time in the formulation-treated children, concluding that it was safe and decreased the clinical time of bronchiolitis
(Kong et al., 1993; Yuan and Lin, 2000). An herbal complex known as Saiboku-to or Chai-pu-tang, in chinese (TJ-96), has antiinflammatory properties in the treatment of asthma. It consists of the following plants: Bupleurum falaztum Linne, Pinellia ternata Breitenbach, Pork cocos Wolf, Scutelkzriu baiealensis Georgi, Zizyphus vulgaris Lamark, Panax ginseng C. A. Meyer, Magnolia officinalis, Glycyrrhiza glabra L., Perillae frutescens Britton, Zingiber officinale Roscoe. In order to study and confirm these effects, it was carried out in Japan a double-blind randomized placebo- controlled study with 33 adult patients presenting atopic asthma, determined by skin testing and IgE levels in serum. After a four-week period, it was observed that concentrations of eosinophils and ECP (eosinophilic cationic protein) in the serum 
and sputum were significantly lower in patients Saiboku-to-treated and that the same was not observed in placebo. The reduction in patients treated with TJ-96 in percentage of eosinophils was from $9.8 \pm 4.8$ to $5.3 \pm 2.5$ and $13.9 \pm 7.7$ to $5.3 \pm 4.5$ in blood and sputum, respectively, and from $15.6 \pm 7.6$ to $3.7 \pm 1.4 \%$ of ECP in serum and from $729 \pm 326$ to $180 \pm 46 \mathrm{mg} / \mathrm{L}$ of sputum.

Eosinophils are the main component of bronchial inflammation and the EPC the most used marker in bronchial asthma. This reduction confirms that the herbal mixture has indeed a therapeutic potential against asthma. The anti asthmatic activity of Tj-96 is related to a reduction of eosinophil infiltration, not to a bronchodilatation, like the usual mechanism of action of drugs against asthma generally is (Urata et al., 2002).

Respiratory problems such as allergic rhinitis also have herbal therapies in clinical trials. In Sydney it was conducted a double-blind placebo controlled study with 58 patients aged 18 to 65 years who had a history of allergic rhinitis, as measured by serum IgE levels and skin test. The therapy consisted of 11 herbs mixture derived from traditional Chinese medicine, known as Biminne $^{\circledR}$, containing the following plants: Rehmannia glutinosa, Scutellaria baicalensis, Polygonatum sibiricum, Ginkgo biloba, Epimedium sagittatum, Psoralea corylifolia, Schisandra chinensis, Prunus mume, Ledebouriella divaricata, Angelica dahurica and Astragalus membranaceus.

In all patients the level of IgE immunoglobulin in the bloodstream was tested. The trial lasted 12 weeks, and the parameters used in the analysis were daily symptoms day-book, questionnaire about quality of life, visual analog scale and medical evaluation of patients.

It could be observed that some patients in both groups were using nasal anti histamines and steroids. Three months later, after evaluating by visual analog scale, there was a reduction in the use of these medications of $77 \%$ in Biminne group and $13 \%$ in the placebo group. After 12 months, these figures were $41 \%$ and $2 \%$ respectively. Some reported daily symptoms, such as sneezing, had a significant reduction in the use of Biminne ${ }^{\circledR}$ compared to placebo; other symptoms, such as blockage in the nose, nasal itching and itchy eyes, had no significant reduction. As for the nasal congestion, there was no difference between groups. But the analysis by quality of life questionnaire and visual analog scale showed a considerable improvement in all symptoms described in Biminne $^{\circledR}$ treatment compared to placebo. The overall assessment by the physician also achieved significant improvement in because of the treatment with the herbs mixture.

Furthermore, it was observed, at the end of the treatment, that serum levels of $\operatorname{IgE}$ were reduced in the Biminne-treated group. This reduction was from 288 to $238 \mathrm{Ku} / \mathrm{L}$ on the average of patients in this group. The Biminne ${ }^{\circledR}$ mechanism of action formulation is unknown. What was known was the effect of some of its previously studied plants such as Scutellaria and Schisandra in reducing IgE levels. Also the $S$. baicalensis plant is a component of a Chinese formulation known as MSSM-002, which has anti-inflammatory, anti asthmatic and immunomodulating activity in animal models. Rehmannia glutinosa is present in the formulation Zemaphyte ${ }^{\circledR}$, which has demonstrated improvement in the atopic eczemain human studies (Hu et al., 2002).

\section{Skin inflammation}

A traditional Chinese herbal medicine formulation comprising for ten herbs was used in clinical studies in patients with atopic dermatitis. Sheehan et al. demonstrated, in a doubleblind placebo-controlled study in 40 adult patients with atopic eczema, that the formulation was effective in treating the disease when compared with placebo (Sheehan et al., 1992). A similar study was conducted on 47 children, showing positive results of the formulation relative to placebo. Twelve months after the treatment, the efficacy of the formulation was ascertained in 37 of the children. 18 showed $90 \%$ improvement in the symptoms, five, a lesser degree of improvement, and 14 abandoned treatment (Sheehan and Atherton, 1994; Yuan and Lin, 2000).

The mixture contained the following plants: Ledebouriella seseloides, Potentilla chinensis, Anebia clematidis, Rehmannia glutinosa, Paeonia lactiflora, Lophatherum gracile, Dictamnus dasycarpus, Tribulus terrestris, Glycyrrhiza uralensis and Schizonepeta tenuifolia. They were commercially obtained in a tea bag with the name of Zemaphyte ${ }^{\circledR}$. The placebo consisted of a mixture of herbs and components without any known action about atopic dermatitis, but with similar smell and taste (Sheehan et al., 1992).

In a more recent review on the use of Chinese herbs mixture in the treatment of atopic eczema, it was said that, while two studies of Sheehan demonstrated efficient treatment, a study made in China, by Fung, showed no differences between placebo and the formulation. The raised hypotheses for this fact were a smaller dose, differences in dropout rates and racial differences in the participants. Anyway, they highlight that the base of the traditional Chinese medicine is focused on the individual characteristics of each patient, unlike the occidental model, which uses it as a fixed commercial formulation. And the real potential of the ten herbs at different doses and combinations is still unknown (Deng et al., 2013).

In this study on the use of plant extracts for the treatment of psoriasis in clinical trials, Mahonia aquifolium, Indigo naturalis and Aloe vera have demonstrated positive results in the treated patients (evaluated separately to each plant). The kukui nut oil derived from the plant Aleurites moluccana have shown improvement, but not significant. And the Camptotheca acuminata gel showed significant improvement relative to placebo and to dosage forms as an ointment and dye (Deng et al., 2013).

\section{Inflammation of the bones and joints}

A formulation of 15 herbs was tested in a double-blind trial in patients with acute gouty arthritis. Among these herbs was Scutellaria baicalensis, whose compounds named baicalein and baicalin have antihistamine activity, and G. uralensis, which contains glycyrrhizic acid, glycyrrhetinic aid and glycyrrhizin, which enhance and prolong the effects of cortisone. This formulation was tested by comparing the effects of indomethacin 
and allopurinol. However, there was no significant improvement using the herbal formulation, demonstrating that it was ineffective against acute gout arthritis or that the treatment time was inadequate (Yuan and Lin, 2000).

The anti-inflammatory properties of ginger (Zingiber officinale) have been known since ancient times, and its discovery as an inhibitor of prostaglandin biosynthesis has been confirmed by several studies (Grzanna et al., 2005). One of them is related to the treatment of osteoarthritis, in which was performed a doubleblind randomized clinical trial with 120 patients at a hospital in Iran, aged 52 and 64, who suffered from osteoarthritis with moderate to severe pain. The patients were divided into three groups: placebo, ibuprofen and ginger extract, and the evaluated aspects were: visual analogue scale for pain, gelling pain, joint swelling measurement and joint motion slope measurement. After a month treatment, it was noted that the scores of visual analogue scale and stiffness after motionlessness were significantly higher to the placebo group than to both groups (ginger and ibuprofen extract), which did not differ significantly differences among themselves. Therefore, it has been concluded and confirmed that the ginger extract is effective in the symptomatic treatment of osteoarthritis as well as ibuprofen. This also indicates that the extract may be a good alternative to the use of nonsteroidal antiinflammatory drug, promoting a reduction in the use of these drugs (Masoud Haghighi et al., 2005).

Still on osteoarthritis it was carried out in Korea a clinical trial to test the efficacy of a three Chinese herbs mixture: Clematis mandshurica, Trichosanthes kirilowii and Prunella vulgaris. The study was a double-blind placebo controlled study with 96 patients whose ages ranged from 35 to 75 years and who had knee osteoarthritis. Four weeks later, patients treated with 200 , 400 or $600 \mathrm{mg}$ of the formulation had a significant improvement of the symptoms, compared to placebo; they did not show differences between varying dosages of mixing plants (Jung et al., 2001).

Rheumatoid arthritis is a very common chronic inflammatory disease that affects various joints. Usually its treatment is based on NSAIDs. Several studies on various plants and mechanisms of action have been done in order to cure this disease. One can quote, for example, an early 1989 study, about an herbaceous plant that grows in southern China, Tripterygium wilfodii Gancho $F$. Seventy patients with rheumatoid arthritis participated in a double-blind placebo-controlled study. At the end of treatment, three months later, patients who received herbal therapy showed significant improvement compared to placebo in all the observed parameters: tenderness score, swelling count, morning stiffness and grip strength. The symptoms began to be noted in the first four weeks (Soeken et al., 2003).

\section{Inflammation of the digestive tract}

In order to evaluate the effects of a herbal mouthwash on oral bleeding caused by gingivitis, a double-blind controlled clinical trial was conducted in northeastern Brazil with 55 patients of both sexes, over 18 years, with gingivitis or chronic periodontitis. The plants in question were Punica granatum Linn. e Matricaria recutita Linn., better known as pomegranate and chamomile, respectively. The first stands out for its antiinflammatory and antimicrobial activities in popular use, but with the majority of in vivo and in vitro studies. The second has been most widely used over the years in the treatment of inflammatory diseases, including in the oral cavity.

The clinical trial was conducted comparing the effects of extracts from two plants with Chlorhexidine, a reference drug found to be effective in the treatment of gingivitis, but with some adverse effects. It was observed that the three groups (pomegranate extract, chamomile extract and chlorhexidine) were effective in reducing oral bleeding, thus indicating that the extracts can be used for that therapeutic purpose (Batista et al., 2014).

After in vitro studies with Artemisia absinthium extract on tumor necrosis factor alpha, a pro inflammatory cytokine whose production is considerably increased in Crohn's disease, it was conducted a controlled clinical study with 20 patients affected by that disease. At the end of six weeks, there was a reduction in the Crohn's disease activity index in the ten patients treated with wormwood from 275 to 175 , and a decrease in the TNF- $\alpha$ levels from 24.5 to $8.0 \mathrm{pg} / \mathrm{ml}$. In the control group the decrease was slight: from 282 to 260 and from 24.7 to $22.1 \mathrm{pg} / \mathrm{mL}$, respectively (Krebs et al., 2010).

\section{Autoimmune inflammatory diseases}

Ankylosing spondylitis is a chronic autoimmune disease that affects the connective tissues, causing inflammation in the joints of the spine, hip, knees and shoulders. In this context, the lung function is also affected due to its high vascularity and the presence of tissue. Xinfeng ${ }^{\circledR}$ is a Chinese herbal therapy consisting of Astragalus membranaceus, Astragalus mongholicus, Coix lacryma-jobi, Tripterygium wilfordii, Scolopendra subspinipes, which is under patent (number 8658748).

And to assess whether this herbal therapy improves lung function in patients with ankylosing spondylitis, it was conducted a randomized study in China, with 120 patients with the disease, in which sixty were capsules of Xinfeng-treated and the others with Salazopyrin (sulfasalazine). Sixty healthy subjects took part of it as a control group, which presented significant differences between patients with the disease in regard to respiratory function tests and cytokine levels in serum and oxidative stress. After three months treatment, it was found that the clinical therapeutic effect observed in Xinfeng group was significantly higher than the group treated with sulfasalazine. It was also concluded that Xinfeng ${ }^{\circledR}$ improves joint pain, column, and improves lung function. Xinfeng ${ }^{\circledR}$ is believed to be related with the inhibition of nuclear factor KB p65 signaling pathway and nitric oxide (Liu et al., 2013; Liu et al., 2014).

Systemic lupus erythematosus is an autoimmune inflammatory disease that affects any tissue or organ in the body. Treatment usually is based on corticosteroids and immunomodulators, but these cause a number of serious adverse effects. A clinical study was conducted in China in order to 
evaluate the therapeutic effects of two united formulations of traditional Chinese medicine. They are: Liu-Wei-Di-Huang Wan, consisting of Rehmannia glutinosa, Cornus officinalis, Dioscorea opposita, Alisma orientalis, Paeonia suffruticosa and Poria cocos; and Dan Chi-San, composed by Radix Salviae Miltiorrhizae, Radix Notoginseng, Borneolum Syntheticum and polyethylene glycol as excipient.

The study was a randomized double-blind, and 53 patients with systemic lupus erythematosus were recruited. A group of patients was treated with $2.7 \mathrm{~g}$ of Liu-Wei-Di-Huang Wan and $125 \mathrm{mg}$ of Dan-Chi San, totaling $100 \%$ of the combination of two formulations, which was called Dan Chi-Wei Liu combination. And the control group was treated with $10 \%$ of Liu-Wei-Di-Huang Wan plus $90 \%$ of starch and $10 \%$ of Dan-Chi San plus $90 \%$ of starch. Both groups received standard therapy in addition to the formulations. The results showed that the herbal therapy was safe and could have an effect in reducing the disease. But six months later, a gradual reduction in steroid dose was not possible. A follow-up study would be required to confirm the effect (Liao et al., 2011).

\section{Neurological inflammations}

The saffron flower (Crocus sativus) has therapeutic potential for various diseases. One of them, which is worth mentioning here, is the antidepressant. In vitro studies, in vivo and in human beings have shown antioxidant, anti-inflammatory, serotonergic mechanism, neuroendocrine and neuroprotective effects. According to a review on the turmeric use for depression, it was found six clinical studies about the use of flower extract (petal or stigma).

Two of these studies were Placebo-controlled and the extract was effective in treating depression. Four studies compared the extract with an antidepressant medication, in which similar results were found among the groups. The studies ranged from 6 to 8 weeks with 230 patients in total. In recent years, it has been investigated the relationship of inflammation and the immune system dysregulation with depression due to the increase of Creactive protein, IL-6 and TNF- $\alpha$ (Lopresti and Drummond, 2014). Coronary artery bypass surgery is a very common surgical procedure that often generates effects such as cognitive dysfunction in post surgery patients. From the hypothesis that Valeriana officinalis root extract can prevent cognitive dysfunction in patients undergoing this surgery by stimulating serotonin receptors and anti-inflammatory activity, a clinical trial was conducted to evaluate this activity. Sixty-one patients were recruited in Iran aged between 30 and 70 years, in a Double-blind placebo-controlled randomized trial.

It was observed by the Mini Mental State Examination (MMSE) a decrease of the average points in the preoperative test until the tenth day, and an increase in the sixtieth day for patients treated with capsules of valerian extract. In the placebo group, this reduction was significant until the tenth day and remained constant on the sixtieth day. According to researchers, cognitive dysfunction and neuro inflammation may be related, and inflammation is one of the mechanisms that cause this disorder (Hassani et al., 2015).

\section{DISCUSSION}

Were listed eleven diseases separate in six categories. As noted, the most of the studies consisted of randomized doubleblind, which offers greater reliability on the results. Seven studies were placebo-controlled, three used a reference drug as control and one used both controls. In the case of lupus, the control was done with $10 \%$ herbal formulation and $90 \%$ starch. In most studies it was observed a superior effect in herbal formulation than placebo or a comparable effect to reference drug. The outcomes measured varied according to the condition. In some studies it was observed blood parameters related to inflammation such as eosinophils and IgE. In other studies reductions were observed in clinical symptoms. And in most studies the results were quantified in scores, scales and index of diseases.

Some works such as Hassani et al. about cognitive dysfunction after coronary artery bypass were not included in the table 1 because it is not an inflammatory disease. But it is cited in the review to show how the inflammatory processes are present in various conditions (Hassani et al., 2015).

In a study of Basu et al, a formulation of a vaginal cream containing extracts of curcumin, reetha, amla and Aloe vera was evaluated in a clinical trial in women with papillomavirus infection. The anti-microbial, anti-inflammatory, anti-HPV and anti-HIV activity of the components are known. But this article was not included in this study because it is not an inflammatory disease, but an inflammation caused by an infection of parasite. Data such as this one indicate that inflammation is typically present not only in inflammatory diseases which are the focus of this review (Basu et al., 2014).

It was also observed that in most studies plant extracts used consisted of a mixture of more than one plant. The multicomponent phytotherapy use has gained importance in the scientific context. According to Rather et al., drugs used to act on a single target may be non-effective in combating multiinflammatory disorders, while herbal combinations, show lower propensity to resistance and a good strategy in fighting multifactorial diseases due to its action in synergy and holistically. Traditional medicinal systems such as Traditional Chinese Medicine (TCM) and the Indian Ayurveda possess this approach (Rather et al., 2013).

An example of this phenomenon is the substance tetrahydrocannabinol extracted from Cannabis sativa, whose antispasmodic action is more present in the extract, in which the proportion is $20 \%$, than in isolated and pure $\mathrm{TCH}$. This fact is believed to be due to the synergism of THC with cannabidiol (Baker et al., 2000).

It is worth mentioning the importance of studying the synergistic mechanisms among the substances contained in plant extracts, for the interactions between the extract constituents can, to some extent, protect the active ingredient from degradation by 
enzymes and modify transport mechanisms across cell membranes (Rather et al., 2013).

Traditional Chinese medicine has a philosophy based on the balance restoration and maintenance. The study of classical Chinese pharmacopoeia takes to meet an immense amount of vegetables formulations used in the therapy of various diseases. Generally, the mixtures containing up to 20 herbs (Yuan and Lin, 2000).

These results still lack of many pharmacological studies in order to elucidate the mechanism of action of plant extracts because under inflammatory conditions there is a range of different mechanisms of action in which drugs can act. And as it is not assessed a single molecule and its interaction with cellular receptors in the extracts, this analysis becomes more complex.

\section{CONCLUSION}

Taking into account the data analyzed in this study, we conclude that many plants have anti-inflammatory activity, and clinical trials were conducted for many of them. Mostly therapies used in clinical trials were based on various herbal formulations. The ancient knowledge of traditional Chinese medicine applied to the Western context has been discovered and increasingly gained greater importance. It is believed that numbers shell grow over the next few years and by means of different dosage forms, reaching the pharmaceutical market and becoming more recognized by medicine.

\section{Financial support and sponsorship: Nil.}

Conflict of Interests: There are no conflicts of interest.

\section{REFERENCES}

Baker D, Pryce G, Croxford JL, Brown P, Pertwee RG, Huffman JW, Layward L. Cannabinoids control spasticity and tremor in a multiple sclerosis model. Nature, 2000; 404(6773): 84-87.

Balbi AL, Barbosa RA, Lima MCP, Almeida DBD. Estudo comparativo das complicações terapêuticas no lúpus eritematoso sistêmico e nas glomerulopatias idiopáticas. Rev Ass Med Brasil 2001; 47(4): 296301.

Batista AL, Lins RD, Souza CR, Nascimento BD, Moura BN, Alves CFJ. Clinical efficacy analysis of the mouth rinsing with pomegranate and chamomile plant extracts in the gingival bleeding reduction. Complement Ther Clin Pract, 2014; 20(1): 93-98.

Campos HS. Asma: suas origens, seus mecanismos inflamatórios e o papel do corticosteróide. Rev Bras Pneumol Sanit, 2007; 15(1): 47-60.

Basu P, Dutta S, Begum R, Mittal S, Dutta P, Bharti AC, Panda CK, Biswas J, Dey B, Talwar GP, Chandra Das B. Clearance of Cervical Human Papillomavirus Infection by Topical Application of Curcumin and Curcumin Containing Polyherbal Cream: A Phase II Randomized Controlled Study. Asian Pac J Cancer Prev, 2013; 14(10): 5753-5759

Bombardier C, Laine L, Reicin A, Shapiro D, Burgos-Vargas R, Davis B, Day R, Ferraz MB, Hawkey CJ, Hochberg MC, Kvien TK, Schnitzer TJ. Comparison of Upper Gastrointestinal Toxicity of Rofecoxib and Naproxen in Patients with Rheumatoid Arthritis. The New England Journal of Medicine, 2000; (343): 1520-1528.

Deng S, May BH, Zhang AL, Lu C, Xue CC. Plant extracts for the topical management of psoriasis: a systematic review and metaanalysis. Br J Dermatol, 2013; 169(4): 769-782.
Cechinel-Filho V, Yunes RA. Estratégias para a obtenção de compostos farmacologicamente ativos a partir de plantas medicinais. Conceitos sobre modificação estrutural para otimização da atividade. Quimica Nova, 1998; 21(1): 99-105.

Fox LP, Merk HF, Bickers DR, Brunton LL, Lazo JS, Parker KL. 2007. Farmacologia dermatológica. In: As Bases Farmacológicas da Terapêutica de Goodman e Gilman. McGraw-Hill. Rio de Janeiro - Brasil: 1531.

Grzanna R, Lindmark L, Frondoza CG. Ginger: an herbal medicinal product with broad anti-inflammatory actions. J Med Food, 2005; 8(2): 125-132.

Gurib-Fakim A. Medicinal plants: traditions of yesterday and drugs of tomorrow. Mol Aspects Med, 2006; 27(1): 1-93.

Hassani S, Alipour A, Darvishi Khezri H, Firouzian A, Emami Zeydi A, Gholipour Baradari A, Ghafari R, Habibi WA, Tahmasebi H, Alipour F, Ebrahim ZP. Can Valeriana officinalis root extract prevent early postoperative cognitive dysfunction after CABG surgery? A randomized, double-blind, placebo-controlled trial. Psychopharmacology (Berl), 2015; 232(5): 843-850.

Hu G, Walls RS, Bass D, Ramon B, Grayson D, Jones M, Gebski V. The Chinese herbal formulation biminne in management of perennial allergic rhinitis: a randomized, double-blind, placebo-controlled, 12-week clinical trial. Ann Allergy Asthma Immunol, 2002; 88(5): 478487.

Laurindo IMM, Ximenes AC, Lima FaC, Pinheiro GRC, Batistella LR, Bertolo MB, Alencar P, Xavier RM, Giorgi RDN, Ciconelli RM, Adominski RSC. Artrite Reumatóide: Diagnóstico e Tratamento. Revista Brasileira de Reumatologia, 2004; 44(6): 435-442.

Jung YB, Roh KJ, Jung JA, Jung K, Yoo H, Cho YB, Kwak WJ, Kim DK, Kim KH, Han CK. Effect of SKI 306X, a new herbal antiarthritic agent, in patients with osteoarthritis of the knee: a double-blind placebo controlled study. Am J Chin Med, 2001; 29(3-4): 485-491.

Kim HP, Son KH, Chang HW, Kang SS. Anti-inflammatory plant flavonoids and cellular action mechanisms. J Pharmacol Sci, 2004; 96(3): 229-245.

Kong XT, Fang HT, Jiang GQ, Zhai SZ, O'Connell DL, Brewster DR. Treatment of acute bronchiolitis with Chinese herbs. Archives of Disease in Childhood, 1993; 68: 468-471.

Krebs S, Omer TN, Omer B. Wormwood (Artemisia absinthium) suppresses tumour necrosis factor alpha and accelerates healing in patients with Crohn's disease - A controlled clinical trial. Phytomedicine, 2010; 17(5): 305-309.

Kummer CL, Coelho TCRB. Antiinflamatórios Não Esteróides Inibidores da Ciclooxigenase-2 (COX-2): Aspectos Atuais. Rev Bras Anestesiol, 2002; 52(4): 498 - 512.

Liao YN, Liu CS, Tsai TR, Hung YC, Chang SJ, Lin HL, Chen YC, Lai HM, Yu SF, Chen CJ. Preliminary study of a traditional Chinese medicine formula in systemic lupus erythematosus patients to taper steroid dose and prevent disease flare-up. Kaohsiung J Med Sci, 2011; 27(7): 251257.

Liu J, Huang CB, Wang Y, Xu GQ, Cheng YY, Feng YX, Liu L, Qi YJ. Chinese herbal medicine Xinfeng Capsule in treatment of rheumatoid arthritis: study protocol of a multicenter randomized controlled trial. J Integr Med, 2013; 11(6): 428-434.

Liu J, Qi Y, Zheng L, Cao Y, Wan L, Ye W, Fang L. Xinfeng capsule improves pulmonary function in ankylosing spondylitis patients via NF-KappaB-iNOS-NO signaling pathway. J Tradit Chin Med, 2014; 34(6): 657-665.

Liu MF, Kohsaka H, Sakurai H, Azuma M, Okumura K, Saito I, Miyasaka N. The presence of costimulatory molecules CD86 and CD28 in rheumatoid arthritis synovium. Arthritis Rheum, 1996; 39(1): 110-114.

Lopresti AL, Drummond PD. Saffron (Crocus sativus) for depression: a systematic review of clinical studies and examination of underlying antidepressant mechanisms of action. Hum Psychopharmacol, 2014; 29(6): 517-527.

Luengo MB. A historical revision of the main immunological events and pharmacology in the search of the understanding and treatment of inflammatory diseases. Revista Eletrônica de Farmácia, 2005; 2(2): 64 72. 
Masoud Haghighi, Ali Khalvat, Tayebeh Toliat, Jallaei S. Comparing the effects of ginger (Zingiber officinale) extract and ibuprofen on patients with osteoarthritis Arch Iranian Med, 2005; 8(4): $267-271$.

Rang HP, Dale MM, Ritter JM, Flower RJ, Henderson G. 2012. Fármacos anti-inflamatórios e imunossupressores. In: Rang \& Dale Farmacologia. Elsevier. Rio de Janeiro, Brasil: 318-335.

Rather MA, Bhat BA, Qurishi MA. Multicomponent phytotherapeutic approach gaining momentum: Is the "one drug to fit all" model breaking down? Phytomedicine, 2013; 21(1): 114.

Sato EI, Voltarelli JC, Donadi EA, Carvalho IFD, Arruda LK, Sarti W. 2008. Lúpus Eritematoso Sistêmico. In: Imunologia Clínica na Prática Médica. Atheneu: 651-661.

Scimmer BP, Parker KL, Brunton LL, Lazo JS 2007. Hormônio Adrenocorticotrópico; esteróides adrenocorticais e seus análogos sintéticos; inibidores da síntese e das ações dos hormônios adrenocorticais. In: Goodman \& Gilman - As Bases Farmacológicas da Terapêutica McGraw-Hill. Rio de Janeiro - Brasil: 1447.

Sheehan MP, Rustin MHA, Atherton DJ, Buckley C, Harris DJ, Brostoff J, Ostlere L, Dawson A. Efficacy of traditional Chinese herbal therapy in adult atopic dermatitis. Lancet, 1992;340:13-7.
Smyth EM, Grosser T, Fitzgerald GA, Brunton LL, Chabner BA, Knollmann BC. 2011. Autacoides derivados dos lipídeos: eicosanoides e fator ativador plaquetário. In: As Bases Farmacológicas da Terapêutica de Goodman e Gilman. MG Hill. Rio de Janeiro, Brasil: 937,939.

Soeken KL, Miller SA, Ernst E. Herbal medicines for the treatment of rheumatoid arthritis: a systematic review. Rheumatology (Oxford), 2003; 42(5): 652-659.

Urata $\mathrm{Y}$, Yoshida $\mathrm{S}$, Irie $\mathrm{Y}$, Tanigawa $\mathrm{T}$, Amayasu $\mathrm{H}$, Nakabayashi M, Akahori K. Treatment of asthma patients with herbal medicine TJ-96: a randomized controlled trial. Respir Med, 2002; 96(6): 469-474.

Yuan R, Lin Y. Traditional Chinese medicine: an approach to scientific proof and clinical validation. Pharmacol Ther, 2000; 86(2): 191198.

\section{How to cite this article:}

Souza EPBSS, Faria RX, Rocha LM. Clinical trials studies of plant extracts with anti-inflammatory activity. J App Pharm Sci, 2016; 6 (12): 224-232. 